\title{
Protective Effect of Ethanol Extract of Roots of Tetracera akara (Burm. f.) Merr., on Carbon Tetrachloride-induced Hepatic Injury in Wistar Rats
}

\author{
R. R. NAIR, S. R. SUJA*, V. VILASH, A. L. ANEESHKUMAR, S. RAJASEKHARAN AND B. S. BIJU KUMAR ${ }^{1}$
}

Ethnomedicine and Ethnopharmacology Division, Jawaharlal Nehru Tropical Botanic Garden and Research Institute, Palode, Thiruvananthapuram-695 562, ${ }^{1}$ Department of Zoology, M G College, Thiruvananthapuram-695 004, Kerala, India

Nair et al.: Hepatoprotective effect of Tetracera akara (Burm. f.) Merr., on $\mathrm{CCl}_{4}$-induced hepatic injury in Wistar rats

\begin{abstract}
The present study was carried out to evaluate the hepatoprotective activity of ethanol extract of roots of Tetracera akara against carbon tetrachloride-induced hepatotoxicity in Wistar rats. Ethanol extract of roots of Tetracera akara $(50,150$, and $300 \mathrm{mg} / \mathrm{kg})$ was administered orally once daily during the study. The hepatoprotective effect of the extract was assessed using various biochemical parameters of hepatic injury like alanine transaminase, aspartate transaminase, alkaline phosphatase, $\gamma$-glutamyl transferase, serum bilirubin, triglycerides, total cholesterol and total protein along with the estimation of antioxidant status of the liver tissue (superoxide dismutase, catalase, glutathione and malondialdehyde levels) and histopathological evaluation. The substantially elevated serum enzymatic levels of serum transaminases, alkaline phosphatase and total bilirubin as a result of carbon tetrachloride administration were significantly restored towards normal by the plant extract. The ethanol extract significantly increased the levels of superoxide dismutase, catalase and non-enzymatic antioxidant glutathione in the drug-treated group. The histopathological observations were in correlation with the biochemical findings. Animals treated with higher doses of plant extract showed almost normal hepatic architecture with normal hepatocytes and reduced steatosis, apoptosis, centrilobular necrosis, ballooning degeneration, fatty deposition, which provided further evidence to the hepatoprotective activity and the most effective dose was found to be $300 \mathrm{mg} / \mathrm{kg}$. In conclusion, Tetracera akara extract exerted hepatoprotective effect against acute hepatotoxicity induced by carbon tetrachloride in Wistar rats, which could be due to the bioactive phytoconstituents present in the extract and these findings provide impetus for the development of a novel hepatoprotective herbal drugs.
\end{abstract}

Key words: Tetracera akara, Kani tribe, Pattuvalli, carbon tetrachloride, hepatotoxicity

Tetracera akara (Burm. f.) Merr. (Dilleniaceae) is a woody climber, locally known as 'Pattuvalli', distributed in the Western Ghats region of Kerala and Tamil Nadu. The roots of T. akara is reported to be used by the Kani tribe of Kerala to cure various liver disorders ${ }^{[1]}$. The results from previous studies of comparative in vitro antioxidant studies revealed that $T$. akara ethanol fraction is rich in bioactive phytoconstituents like phenols and flavonoids with good antioxidant potential ${ }^{[2]}$ and is safe for oral administration in experimental animals ${ }^{[3]}$. Hepatoprotective effect of ethanol fraction of roots of T. akara against paracetamol-induced acute liver damage has been reported earlier, which revealed that the ethanol fraction of T. akara showed antihepatotoxic effect against drug over dose in Wistar rats ${ }^{[4]}$. However,

*Address for correspondence E-mail: sujasathyu@gmail.com

September-October 2019 the protective effect of $T$. akara against chemicalinduced liver injury has not been evaluated yet which is necessary to scientifically validate the hepatoprotective effect of T. akara against various models of hepatic injury.

The use of many halogenated alkanes such as carbon tetrachloride $\left(\mathrm{CCl}_{4}\right)$, chloroform $\left(\mathrm{CHCl}_{3}\right)$ or iodoform $\left(\mathrm{CHI}_{3}\right)$ was banned or severely restricted because of their distinct toxicity. Yet $\mathrm{CCl}_{4}$ continues to be used

This is an open access article distributed under the terms of the Creative Commons Attribution-NonCommercial-ShareAlike 3.0 License, which allows others to remix, tweak, and build upon the work non-commercially, as long as the author is credited and the new creations are licensed under the identical terms

Accepted 01 August 2019

Revised 07 May 2019

Received 03 December 2018

Indian J Pharm Sci 2019;81(5):859-867 
today as a model substance to elucidate the mechanisms of action of hepatotoxic effects and to evaluate the hepatoprotective potential of various herbal extracts/ natural compounds ${ }^{[5]} . \mathrm{CCl}_{4}$-induced hepatotoxicity model closely resembles human cirrhosis ${ }^{[6]}$ and can induce free radical mediated hepatitis in humans and non-human primates ${ }^{[7]}$. At low doses, $\mathrm{CCl}_{4}$ leads to transient effects such as loss of $\mathrm{Ca}^{2+}$ sequestration, impairment of lipid homeostasis, release of noxious or beneficial cytokines and apoptotic events recovered by regeneration of hepatocytes. On the other hand, higher doses or longer exposure of $\mathrm{CCl}_{4}$ is more serious and permanent, develop over a longer period of time such as fatty degeneration, thickening and scarring of connective tissue and deposition of extracellular matrix resulting in fibrosis, which when left untreated may lead to cirrhosis and even hepatocellular carcinoma. The liver is the principal site for $\mathrm{CCl}_{4}$-induced toxicity, even though there is no specific receptors for its actions, pathological changes have been identified at the biochemical and the ultrastructural level. Endoplasmic reticulum, plasma membrane, mitochondria and Golgi apparatus are the main subcellular structures of hepatocytes affected by $\mathrm{CCl}_{4}$ exposure, soliciting the hypothesis that primarily lipid-containing structures of the cell are affected by $\mathrm{CCl}_{4}^{[8,9]}$. The aim of the present study was to investigate the protective effects of ethanol fraction of T. akara on chemically-induced $\left(\mathrm{CCl}_{4}\right)$ acute liver damage in experimental animals.

\section{MATERIALS AND METHODS}

Tetracera akara (Burm. f.) Merr. roots were collected from Kottoor ( $\mathrm{N}^{\circ} 35^{\prime}$ 03.8', E $77^{\circ} 10^{\prime} 54.8^{\prime \prime}$ and altitude $585 \mathrm{~m}$ ), Thiruvananthapuram district of Kerala, India, and authenticated at JNTBGRI, Palode. Voucher specimen was deposited in the Institute's Herbarium (TBGT 86868 dated 08/08/2015).

\section{Preparation of ethanol extract of T. akara root:}

The collected roots were washed in running water, shade dried and powdered. The powder was serially extracted with hexane followed by chloroform and then by $95 \%$ ethanol for $48 \mathrm{~h}$, using a Soxhlet apparatus. The third solvent extract was then filtered and the filtrate was concentrated under reduced pressure in a rotary evaporator, to obtain the ethanol extract with $9.5 \%$ $\mathrm{w} / \mathrm{w}$ of yield. The dry residue was stored at $4^{\circ}$, and at the time of use, was suspended in $0.5 \% \mathrm{v} / \mathrm{v}$ Tween- 80 . This ethanol extract was referred to as TAETH.

\section{Experimental animals:}

Wistar rats (150-175 g) were obtained from the Institute's Animal House (JNTBGRI). All the animals were housed in polypropylene cages under standard conditions at temperature $25 \pm 2^{\circ}$, relative humidity $60 \pm 10 \%$, room air changes $15 \pm 3$ times/h and $12 \mathrm{~h}$ light-dark cycles, fed commercial rat feed (Lipton India Ltd; Mumbai, India) and distilled water ad libitum. Animals were acclimatized for $1 \mathrm{w}$ before the initiation of an experiment. The study was carried out according to National Institute of Health (NIH) guidelines, after getting the approval of the Institute's Animal Ethics Committee (No. B-16/02/2015/EMEP.15).

\section{Biochemical estimations:}

Commercial kits for the estimation of aspartate transaminase (AST), alanine transaminase (ALT), alkaline phosphatase (ALP), $\gamma$-glutamyl transferase (GGT), serum bilirubin (SB), triglycerides (TGL), total cholesterol (TC) and total protein (TP) were purchased from Coral Clinical System, Goa, India.

\section{$\mathrm{CCl}_{4}$-induced hepatotoxicity:}

Wistar rats were divided into 6 groups with 6 animals in each group. Group I, the normal control group received a single daily dose of $0.5 \%$ Tween- 80 ( $1 \mathrm{ml}$ po) on all $5 \mathrm{~d}$ and olive oil ( $2 \mathrm{ml} / \mathrm{kg}$, sc) on $\mathrm{d} 2$ and 3 . Group II, the $\mathrm{CCl}_{4}$ control group, received a single daily dose of $0.5 \%$ Tween-80 ( $1 \mathrm{ml}$ po) on all $5 \mathrm{~d}$ and on the second and third day, received $2 \mathrm{ml} / \mathrm{kg}$ of $\mathrm{CCl}_{4}$ :olive oil (1:1) by sc. Olive oil is an emulsifying agent, which dissolves sufficient $\mathrm{CCl}_{4}$ to induce liver damage and also has no toxicity and other biological activities related to hepatotoxicity. Groups III, IV and V were administered TAETH reconstituted in $0.5 \%$ Tween- 80 at dosages 50 , $150,300 \mathrm{mg} / \mathrm{kg}$, po, respectively for all $5 \mathrm{~d}$ and a single dose of $\mathrm{CCl}_{4}$ :olive oil mixture $(2 \mathrm{ml} / \mathrm{kg}, \mathrm{sc})$, on $\mathrm{d} 2$ and 3, 30 min after TAETH administration. Group VI was administered silymarin, the standard hepatoprotective drug, at a dose of $100 \mathrm{mg} / \mathrm{kg}$, po, on all $5 \mathrm{~d}$ and a single dose of $\mathrm{CCl}_{4}$ :olive oil mixture $(2 \mathrm{ml} / \mathrm{kg}$, sc) on $\mathrm{d} 2$ and 3, 30 min after silymarin administration. On d 5, all animals were sacrificed under mild ether anaesthesia. Blood samples were collected for evaluating the biochemical parameters and liver tissue samples were collected for histological studies.

\section{Estimation of serum biochemical parameters:}

Blood samples collected in test tubes without EDTA were allowed to coagulate for $1 \mathrm{~h}$ at room temperature. 
These were centrifuged at $1500 \mathrm{rpm}$ for $15 \mathrm{~min}$ at $37^{\circ}$ to separate the serum, which was then assayed for plasma markers, ALT, AST, ALP, GGT and lactate dehydrogenase were determined. TP, albumin, total bilirubin and glucose were also estimated using commercial kits purchased from Coral Clinical system, Goa, India.

\section{Estimation of liver tissue parameters:}

Liver samples of all groups were weighed and homogenized separately using a tissue homogenizer. One portion $(10 \% \mathrm{w} / \mathrm{v})$ was homogenized in $50 \mathrm{mM}$, $\mathrm{pH} 7.4$ phosphate buffered saline, which was centrifuged at $6000 \mathrm{~g}$ for $15 \mathrm{~min}$ at $3^{\circ}$ to remove the cell debris, unbroken cells, nuclei and erythrocytes ${ }^{[10]}$. The supernatant was used for the estimation of oxidative stress markers in liver such as catalase (CAT), superoxide dismutase (SOD), reduced glutathione (GSH) and malondialdehyde (MDA).

\section{Estimation of liver CAT:}

CAT activity was measured according to the method described by Aebi ${ }^{[11]}$. Supernatant $(0.1 \mathrm{ml})$ was added to a cuvette containing $1.9 \mathrm{ml}$ of $50 \mathrm{mM}$ phosphate buffer ( $\mathrm{pH}$ 7.0). Reaction was started by the addition of $1.0 \mathrm{ml}$ of freshly prepared $30 \mathrm{mM} \mathrm{H}_{2} \mathrm{O}_{2}$. The rate of decomposition of $\mathrm{H}_{2} \mathrm{O}_{2}$ was measured spectrophotometrically by changes in absorbance at $240 \mathrm{~nm}$. Results were expressed as IU of CAT activity/g wet tissue and the absorbance values were compared with a standard curve generated from known CAT.

\section{Estimation of SOD:}

Superoxide radicals react with tetrazolium in the presence of $\mathrm{NADH}$ and produce formazan blue. SOD removes the superoxide radicals and inhibits the formation of formazan blue. The intensity of colour is inversely proportional to the activity of the enzyme. The reaction mixture contained $1.2 \mathrm{ml}$ sodium pyrophosphate buffer $(\mathrm{pH} 8.3,0.025 \mathrm{M}), 0.1 \mathrm{ml}$ phenazine methosulphate $(186 \mathrm{mM}), 0.3 \mathrm{ml}$ nitroblue tetrazolium $(300 \mathrm{mM}), 0.2 \mathrm{ml} \mathrm{NADH}(780 \mathrm{mM})$ and approximately diluted enzyme preparations and water in a total volume of $3 \mathrm{ml}$. After incubation at $30^{\circ}$ for $90 \mathrm{~s}$, the reaction was terminated by the addition of $1 \mathrm{ml}$ glacial acetic acid. The reaction was stirred vigorously and shaken with $4 \mathrm{ml}$ n-butanol. The colour intensity of the chromogen in the butanol layer was measured at $560 \mathrm{~nm}$ against $\mathrm{n}$-butanol and concentration of SOD were expressed as U/mg protein. The absorbance values were compared with a standard curve generated from known $\mathrm{SOD}^{[12]}$.

\section{Estimation of GSH:}

Homogenized liver samples $(10 \% \mathrm{w} / \mathrm{v}), 0.2 \mathrm{ml}$ were mixed with $1.8 \mathrm{ml}$ of $1 \mathrm{mM}$ EDTA solution. To this, $3 \mathrm{ml}$ precipitating reagent $(1.67 \mathrm{~g}$ of met phosphoric acid, $0.2 \mathrm{~g}$ of EDTA disodium salt, $30 \mathrm{~g}$ sodium chloride in 11 distilled water) was added, mixed thoroughly and kept for $5 \mathrm{~min}$ before centrifugation. To $2 \mathrm{ml}$ of the supernatant, $4.0 \mathrm{ml}$ of $0.3 \mathrm{M}$ disodium hydrogen phosphate solution and $1.0 \mathrm{ml}$ of 5,5-dithiobis(2-nitrobenzoic acid (DTNB) reagent was added and absorbance was read at $412 \mathrm{~nm}$. The absorbance values were compared with a standard curve generated from known $\mathrm{GSH}^{[13]}$.

\section{Estimation of liver MDA:}

MDA in the rat liver was estimated by the modified procedure of Okhawa et al. ${ }^{[14]}$. Supernatant $(1 \mathrm{ml})$ was mixed with $100 \mu \mathrm{l}$ of $8.1 \%$ SDS, $600 \mu \mathrm{l}$ of $20 \%$ acetic acid solution and was kept for 2 min at room temperature. Then $600 \mu \mathrm{l}$ of $0.8 \%$ solution of freshly prepared thiobarbituric acid (TBA) was added, heated at $95^{\circ}$ for $60 \mathrm{~min}$ in a water bath and cooled with ice cold water at $4^{\circ}$. A mixture of n-butanol and pyridine $(15: 1 \mathrm{v} / \mathrm{v})$ were added, shaken vigorously and centrifuged at $10000 \mathrm{rpm}$ for $5 \mathrm{~min}$. The absorbance of the organic layer was measured against blank at $532 \mathrm{~nm}$. The amount of MDA (TBA reactive substance) was calculated using a molar extinction coefficient $1.56 \times 105 \mathrm{M}^{-1} \mathrm{~cm}^{-1}$ and reported as nmoles of MDA/g tissue.

\section{Statistical analysis:}

All the data were expressed as mean \pm standard error of the mean (SEM). The significance of difference among the group was assessed using one way analysis of variance (ANOVA) followed by Dunnett's post-test using GraphPad Prism version 7.00. The $p \leq 0.05$ was considered statistically significant.

\section{RESULTS AND DISCUSSION}

The results indicated that rats administered with $\mathrm{CCl}_{4}$ exhibited severe hepatic damage in when compared to the control rats, which was evident from the elevated levels of liver markers enzymes and decreased level of TP as shown in Table 1. All rats in the group II indicated significant $(\mathrm{p} \leq 0.05)$ increase in serumAST $(246.74 \pm 3.82$ IU/l), ALT (252.24 \pm 3.38 IU/1), ALP (260.16 \pm 2.92 


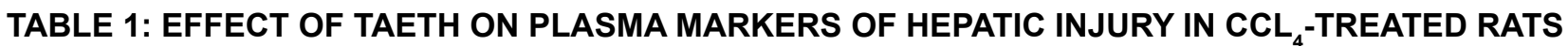

\begin{tabular}{|c|c|c|c|c|c|c|c|c|}
\hline \multirow[b]{2}{*}{$\begin{array}{l}\text { Treatment } \\
\text { groups }\end{array}$} & \multicolumn{8}{|c|}{ Parameters } \\
\hline & $\begin{array}{l}\text { AST } \\
\text { (IU/I) }\end{array}$ & $\begin{array}{c}\text { ALT } \\
\text { (IU/I) }\end{array}$ & $\begin{array}{l}\text { ALP } \\
\text { (IU/I) }\end{array}$ & $\begin{array}{l}\text { GGT } \\
(U / I)\end{array}$ & $\begin{array}{c}\mathrm{SB} \\
(\mathrm{mg} / \mathrm{dl})\end{array}$ & $\begin{array}{c}\mathrm{TC} \\
\text { (mg/dl) }\end{array}$ & $\begin{array}{c}\mathrm{TGL} \\
\text { (mg/dl) }\end{array}$ & $\begin{array}{c}\text { TP } \\
\text { (g/dl) }\end{array}$ \\
\hline $\begin{array}{l}\text { Normal } \\
\text { control }\end{array}$ & $72.26 \pm 2.24$ & $76.18 \pm 1.46$ & $95.38 \pm 1.68$ & $5.78 \pm 1.26$ & $0.38 \pm 0.12$ & $97.46 \pm 1.38$ & $118.23 \pm 2.27$ & $5.72 \pm 0.16$ \\
\hline $\begin{array}{l}\text { Toxin- } \mathrm{CCl}_{4} \\
(1 \mathrm{ml} / \mathrm{kg})\end{array}$ & $246.74 \pm 3.82^{*}$ & $252.24 \pm 3.38^{*}$ & $260.16 \pm 2.92^{*}$ & $21.82 \pm 2.17^{*}$ & $1.82 \pm 0.10^{*}$ & $208.34 \pm 3.18^{*}$ & $249.12 \pm 3.28^{*}$ & $3.82 \pm 0.19 *$ \\
\hline $\begin{array}{l}\mathrm{CCl}_{4}+\mathrm{STD} \\
\text { Silymarin } \\
(100 \mathrm{mg} / \mathrm{kg})\end{array}$ & $82.48 \pm 0.78^{* *}$ & $98.14 \pm 2.42^{* *}$ & $114.54 \pm 2.28^{* *}$ & $6.93 \pm 0.82^{* *}$ & $0.56 \pm 0.06^{* *}$ & $100.32 \pm 2.14^{* *}$ & $121.28 \pm 1.14^{* *}$ & $5.68 \pm 0.12^{* *}$ \\
\hline $\begin{array}{l}\mathrm{CCl}_{4}+\mathrm{TA} \mathrm{ETH} \\
(50 \mathrm{mg} / \mathrm{kg})\end{array}$ & $193.42 \pm 2.18$ & $211.22 \pm 1.84$ & $216.28 \pm 2.12$ & $17.62 \pm 2.04$ & $1.46- \pm 0.06$ & $174.48 \pm 2.82$ & $191.38 \pm 2.11$ & $4.14 \pm 0.18$ \\
\hline $\begin{array}{l}\mathrm{CCl}_{4}+\mathrm{TA} \text { ETH } \\
(150 \mathrm{mg} / \mathrm{kg})\end{array}$ & $96.18 \pm 2.22^{* *}$ & $122.26 \pm 1.12^{* *}$ & $146.38 \pm 3.22^{* *}$ & $11.14 \pm 1.12^{* *}$ & $0.64 \pm 0.14^{* *}$ & $116.16 \pm 2.82^{* *}$ & $130.26 \pm 1.34^{* *}$ & $5.22 \pm 0.10^{* *}$ \\
\hline $\begin{array}{l}\mathrm{CCl}_{4}+\mathrm{TA} \mathrm{ETH} \\
(300 \mathrm{mg} / \mathrm{kg})\end{array}$ & $80.26 \pm 2.24^{* *}$ & $92.34 \pm 1.68^{* *}$ & $124.21 \pm 2.14^{* *}$ & $7.44 \pm 0.38^{* *}$ & $0.59 \pm 0.04^{* *}$ & $106.43 \pm 2.19^{* *}$ & $127.72 \pm 1.38^{* *}$ & $5.49 \pm 0.12^{* *}$ \\
\hline
\end{tabular}

Values are expressed as mean \pm SEM of six values, one way ANOVA followed by Dunnett's multiple comparison test, ${ }^{*} \mathrm{p} \leq 0.05$ compared to normal control, ${ }^{* *} \mathrm{p} \leq 0.05$ compared to $\mathrm{CCl}_{4}$ control

IU/1) GGT (21.82 $\pm 2.17 \mathrm{IU} / 1), \mathrm{SB}(1.82 \pm 0.10 \mathrm{mg} /$ dl), TC $(208.34 \pm 3.18 \mathrm{mg} / \mathrm{dl})$, TGL $(249.12 \pm 3.28 \mathrm{mg} /$ dl) and decreased level of TP $(3.82 \pm 0.19 \mathrm{~g} / \mathrm{dl})$ when compared to control rats. Treatment with TAETH (100, 200 and $300 \mathrm{mg} / \mathrm{kg}$, po) showed significant $(\mathrm{p} \leq 0.05)$ protection against $\mathrm{CCl}_{4}$-induced toxicity in rats in a dose-dependent manner by reducing the elevated AST, ALT, ALP, GGT, SB, TC, TGL levels and increasing the TP level in a dose-dependent manner. For all the biochemical parameters studied, TAETH $(300 \mathrm{mg} / \mathrm{kg}$ ) caused changes in AST- 80.26 \pm 2.24 IU/1, ALT- 92.34 \pm 1.68 IU/1, ALP- $124.21 \pm 2.14$ IU/l, GGT- $7.44 \pm 0.38 \mathrm{IU} / 1$, SB- $0.59 \pm 0.04 \mathrm{mg} / \mathrm{dl}$, TC- $106.43 \pm 2.19 \mathrm{mg} / \mathrm{dl}$, TGL- $127.72 \pm 1.38 \mathrm{mg} / \mathrm{dl}$ and TP- $5.49 \pm 0.12 \mathrm{~g} / \mathrm{dl}$, and these levels indicated that this dose produced significant changes. The reduction in biochemical parameters exhibited by the higher dose of TAETH was almost comparable to that produced by $100 \mathrm{mg} / \mathrm{kg}$ of the standard, silymarin resulting in the levels of AST- $82.48 \pm 0.78$ IU/1, ALT- $98.14 \pm 2.42$ IU/1, ALP- 114.54 \pm 2.28 IU/1, GGT- $6.93 \pm 0.82 \mathrm{IU} / 1$, SB- $0.56 \pm 0.06 \mathrm{mg} / \mathrm{dl}$, TC- $100.32 \pm 2.14 \mathrm{mg} / \mathrm{dl}$, TGL$121.28 \pm 1.14 \mathrm{mg} / \mathrm{dl}$ and TP- $5.68 \pm 0.12 \mathrm{~g} / \mathrm{dl}$.

The level of CAT in liver tissue depleted significantly $(\mathrm{p} \leq 0.05)$ in $\mathrm{CCl}_{4}$-treated animals $(75.62 \pm 3.85 \mathrm{U} / \mathrm{mg}$ protein) when compared to control group (162.30 \pm 6.73 $\mathrm{U} / \mathrm{mg}$ protein). The SOD levels in the group II rats were lowered to $3.14 \pm 0.92 \mathrm{U} / \mathrm{mg}$ and GSH levels were significantly decreased to $8.56 \pm 1.15 \mu \mathrm{mol} / \mathrm{g}$ tissue when compared to the control. All groups of rats administered with different doses of TAETH showed an increase in hepatic CAT, SOD and GSH in a dose-dependent manner. TAETH at $300 \mathrm{mg} / \mathrm{kg}$ offered maximum protection against $\mathrm{CCl}_{4}$-indudced hepatotoxicity in rats, which is evident from the higher levels of CAT (156.84 $\pm 5.33 \mathrm{U} / \mathrm{mg}$ protein), SOD $(15.78 \pm 1.13 \mathrm{U} / \mathrm{mg}$ protein) and GSH $(42.93 \pm 2.67 \mu \mathrm{mol} / \mathrm{g}$ tissue $)$. The MDA levels in group II rats $(59.67 \pm 3.70 \mu \mathrm{mol} / \mathrm{g}$ liver $)$ were higher when compared to the control $(11.56 \pm 1.82$ $\mu \mathrm{mol} / \mathrm{g}$ liver). The MDA levels were found to be lowered in the TAETH-treated groups and the maximum inhibition of lipid peroxidation was shown by $300 \mathrm{mg} / \mathrm{kg}$ of TAETH $(14.89 \pm 1.94 \mathrm{nmol} / \mathrm{g}$ liver) and it is almost comparable to that of in silymarintreated group $(18.45 \pm 2.02 \mu \mathrm{mol} / \mathrm{g}$ liver) as shown in fig. 1.

Histopathological observations revealed that the $\mathrm{CCl}_{4}$-treated rats showed extensive cellular injuries characterized by high hepatocellular degeneration, hydropic changes, macro and micro vesicular steatosis, apoptosis, centrilobular necrosis, ballooning degeneration, fatty deposition and accumulation of inflammatory cells. Silymarin $(100 \mathrm{mg} / \mathrm{kg})$-treated group showed almost normalized hepatic architecture with less centrilobular necrosis and fatty deposition. Moderate level of hepatic protection from $\mathrm{CCl}_{4}$ was achieved with 50 and $150 \mathrm{mg} / \mathrm{kg}$ doses of TAETH. Rats received these doses showed restoration of liver structure with minimal cellular necrosis as shown in fig. 2. Inflammatory changes induced by $\mathrm{CCl}_{4}$ were remarkably reversed by treatment with $300 \mathrm{mg} / \mathrm{kg}$ of TAETH, which almost completely reversed the effects of $\mathrm{CCl}_{4}$ and restored the histological architecture of the liver.

$\mathrm{CCl}_{4}$ metabolism begins with the formation of trichloromethyl free radical, $\mathrm{CCl}_{3} *$ through the action of the mixed function cytochrome P450 oxygenase system of the endoplasmic reticulum by reductive 


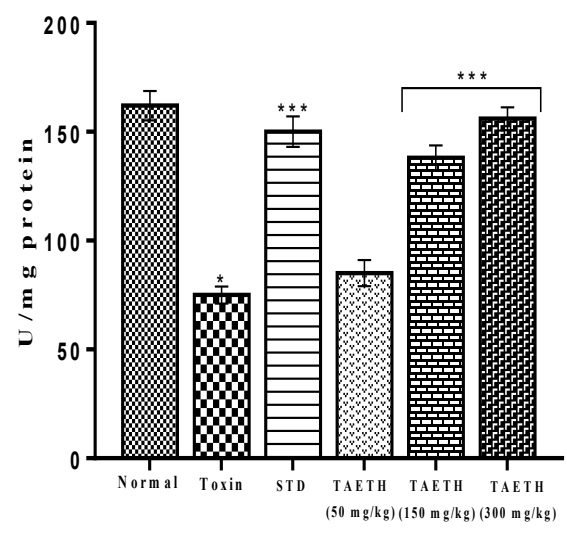

C

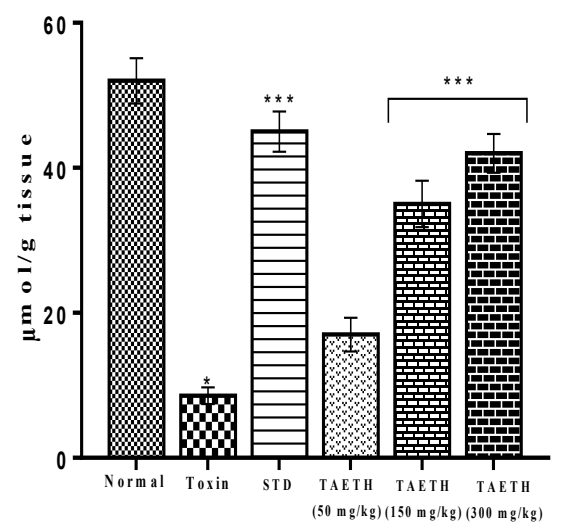

B
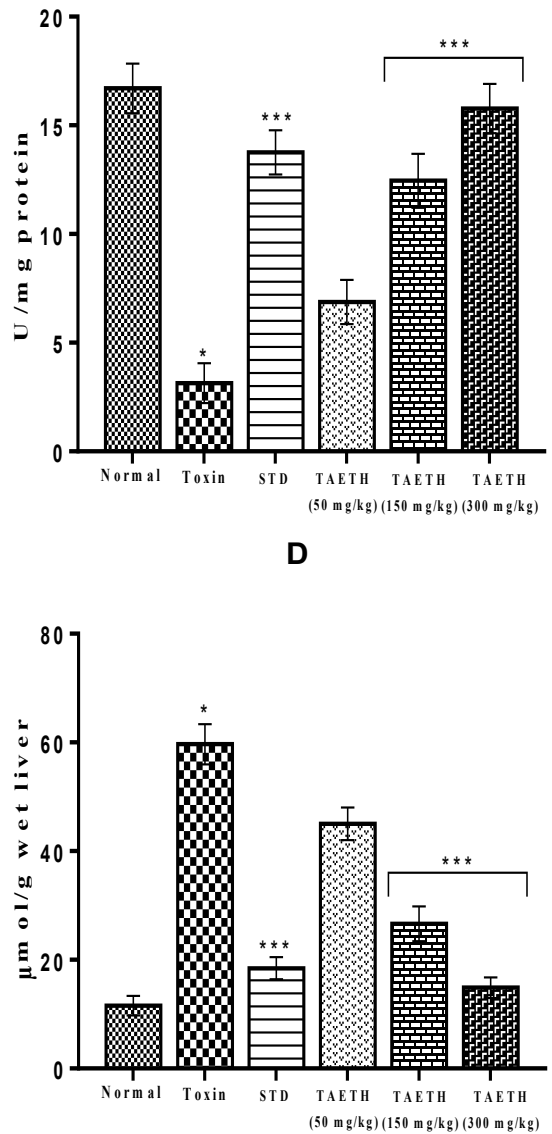

Fig. 1: Effect of TAETH on hepatic enzymes and MDA levels in rats

Effect of treatment with ethanol extract of roots of T. akara (TAETH) on hepatic (A) CAT, (B) SOD, (C) GSH and (D) MDA of Wistar rats treated with $\mathrm{CCl}_{4}$. Values are expressed as mean $\pm \mathrm{SEM}, \mathrm{n}=6$, one way ANOVA followed by Dunnett's multiple comparison test, $* p \leq 0.05$ compared to normal control, $* * * p \leq 0.05$ compared to $\mathrm{CCl}_{4}$-treated rats

cleavage of a carbon-chlorine bond ${ }^{[15]}$. The resulting $\mathrm{CCl}_{3} *$ radical is reactive enough to bind covalently to cytochrome P450 2E1 (CYP2E1), either to the active site of the enzyme or to the heme group causing suicide inactivation leading to the destruction of hepatocytes ${ }^{[16,17]}$. Free radical activation of $\mathrm{CCl}_{4}$ in mitochondria has also been observed and may contribute significantly to its toxicity ${ }^{[18]}$. This $\mathrm{CCl}_{3}{ }^{\text {* }}$ radicals can bind to cellular biomolecules such as nucleic acids, proteins, and lipids there by impairing crucial cellular processes such as lipid metabolism, with the potential outcome of fatty degeneration ${ }^{[19]}$. The reaction product formed between $\mathrm{CCl}_{3}{ }^{*}$ and DNA is thought to function as initiator of hepatic cancer ${ }^{[20]}$. $\mathrm{CCl}_{3}{ }^{*}$ radicals in the presence of oxygen, form the trichloromethylperoxy radical $\left(\mathrm{CCl}_{3} \mathrm{COO} *\right)$, a highly reactive but short-lived species ${ }^{[21]}$, which initiates the chain reaction of lipid peroxidation, attacks and destroys polyunsaturated fatty acids, in particular those associated with phospholipids ${ }^{[2]}$. This affects the permeability of mitochondrial, endoplasmic reticulum and plasma membranes, resulting in the loss of cellular calcium sequestration and homeostasis, which can contribute heavily to subsequent cell damage.

$\mathrm{CCl}_{4}$ administration resulted in functional and morphological changes in the membranes, which might lead to the loss of integrity of endoplasmic reticulum due to the increased lipid peroxidation and leakage of metabolic enzymes located in the intracellular structures ultimately leading to hepatocytic damage ${ }^{[23]}$. The hepatic cells consist of higher concentrations of AST and ALT in cytoplasm and ALP in particular exists in mitochondria. The hepatocytic damage leads to the leakage of plasma ${ }^{[24]}$ causing an increased level of hepatospecific enzymes like AST and ALT in serum indicating cellular leakage and loss of functional integrity of cell membranes in the liver ${ }^{[25]}$. The estimation of serum AST, ALT and ALP levels serve as a means for the indirect assessment of extent and types of hepatocellular damage ${ }^{[26]}$, which was carried 


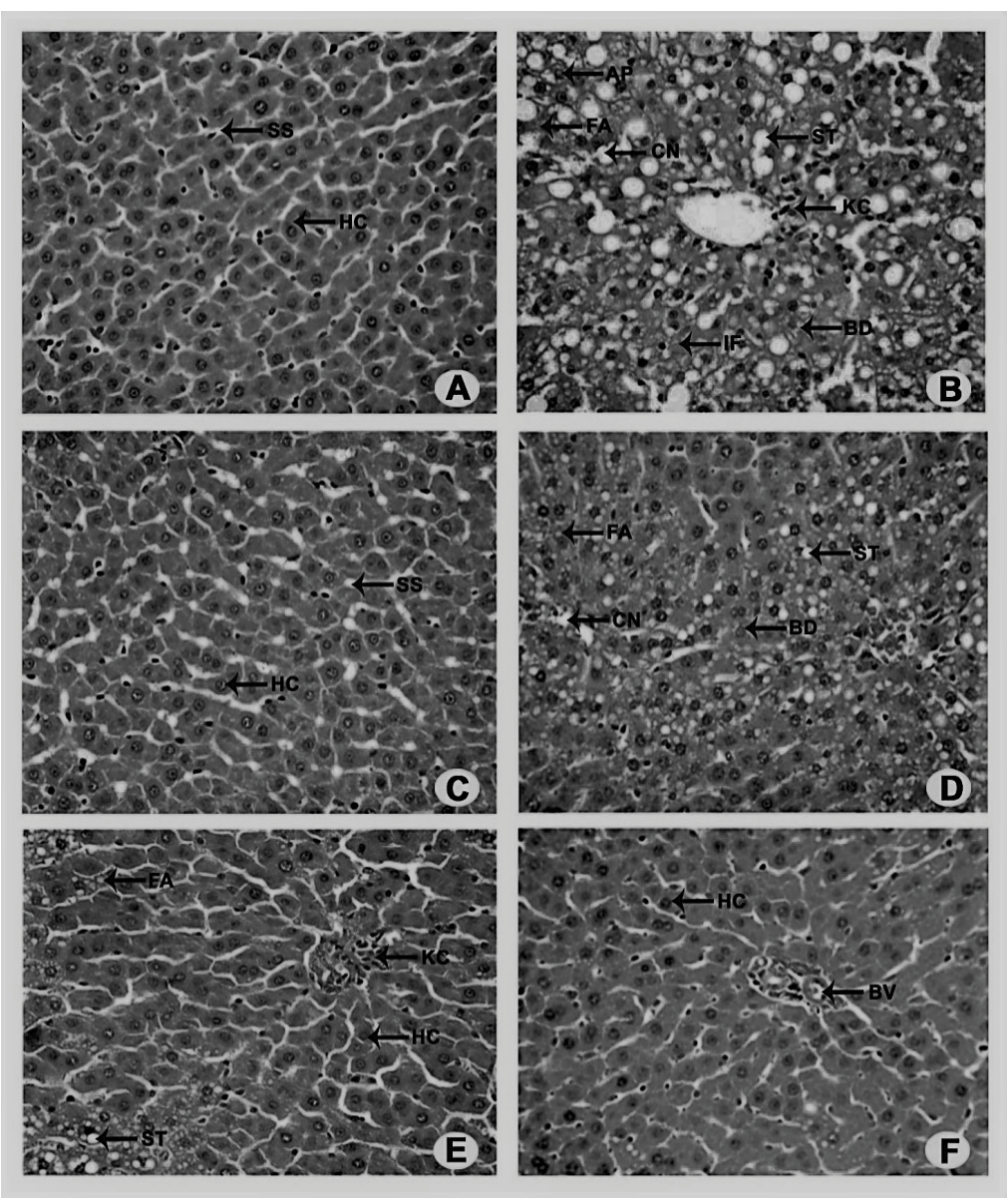

Fig. 2: Effect of TAETH on $\mathrm{CCl}_{4}$-induced liver damage in rats

Effect of ethanol extract of roots of T. akara (TAETH) on $\mathrm{CCl}_{4}$-induced liver damage in Wistar rats $(\times 100, \mathrm{H}$ and $\mathrm{E}$ staining). A: normal control rat liver histology showing normal hepatic architecture. $\mathrm{B}$ : $\mathrm{CCl}_{4}$-treated rat liver with hepatocellular degeneration, steatosis, apoptosis, centrilobular necrosis, ballooning degeneration, fatty deposition and accumulation of inflammatory cells. C: silymarin-treated group showing almost normal hepatic architecture. D, E and F: TAETH (50, $150 \mathrm{and} 300 \mathrm{mg} / \mathrm{kg})$-treated groups showing reduced hepatic damage in a dose-dependent manner (SS- sinusoidal space, HC- hepatic cells, AP- apoptosis, FA- fatty accumulation, $\mathrm{CN}$ - centrilobular necrosis, BD- ballooning degeneration, BV-blood vessel, SC-sinusoidal congestion, KC- Kupffer cells, ST- steatosis, IF- inflammatory cell accumulation)

out in the present investigation. The results obtained in the study showed a significant increase in AST, ALT, ALP and GGT in $\mathrm{CCl}_{4}$-treated group when compared to the control group. The hepatoprotective index of a plant drug can be evaluated by its capability to reduce the injurious effects induced by a hepatotoxin and preserve the normal hepatic physiological mechanisms. Pretreatment with TAETH or standard silymarin to $\mathrm{CCl}_{4}$-treated rats, resulted in a significant decrease in these enzymes in a dose-dependent manner leading to the restoration of functional integrity and stability of the cell membrane by the bioactive phytoconstituents present in the TAETH. An increased concentration of $\mathrm{SB}$ is an indication of erythrocyte degeneration ${ }^{[27]}$ and liver injury caused by a hepatotoxin leads to defective excretion of bile by the liver, which is reflected in the increased SB levels. High levels of SB is observed in $\mathrm{CCl}_{4}$-treated group as a result of defective excretion of bile due to liver injury caused by $\mathrm{CCl}_{4}{ }^{[28]}$. Pre-treatment with TAETH $(300 \mathrm{mg} / \mathrm{kg})$ restored the functional integrity and stability of hepatocytes, which caused decreased level of SB, reduced hepatic injury and improved metabolism.

The serum TC and TGL levels were elevated in $\mathrm{CCl}_{4}-$ treated rats as compared to control rats. Pretreatment with TAETH resulted in significant improvement of lipid metabolism that could be attributed to increased intestinal cholesterol absorption. All these events either individually or in combination lead to increase in serum cholesterol levels in group II rats, but pretreatment with TAETH effectively reduced serum TC to normal level ${ }^{[28,29]} \cdot \mathrm{CCl}_{4}$ treatment caused disruption and disassociation of polyribosomes on endoplasmic reticulum and thereby reducing the biosynthesis of protein. The serum TP level was reduced in $\mathrm{CCl}_{4}$-treated rats mainly due to the blockage or defective protein 
biosynthesis in hepatocyte ${ }^{[30-32]}$ and the administration of TAETH restored the protein synthesis by protecting the polyribosomes effectively and restored normal the serum TP levels.

Co-ordinate actions of various cellular antioxidants in hepatocytes are critical for the effective detoxification of free radicals ${ }^{[32]}$. SOD is the first line of antioxidant enzyme to scavenge ROS via converting $\mathrm{O}_{2}^{-}$to $\mathrm{O}_{2}$ and $\mathrm{H}_{2} \mathrm{O}_{2}$. At high concentrations, $\mathrm{H}_{2} \mathrm{O}_{2}$ is converted to water and $\mathrm{O}_{2}$ by CAT, which is localized predominantly in the peroxisomes ${ }^{[33]}$. GSH is an important nonprotein thiol intracellular antioxidant that scavenges free radicals, protects the liver cells from the harmful effect of ROS and its importance in the detoxification of chemically reactive metabolites has also been extensively documented, with numerous examples of drug-induced toxicity after GSH depletion ${ }^{[34]}$. Decreased level of GSH is also associated with an enhanced lipid peroxidation in $\mathrm{CCl}_{4}$-treated rats. The radical scavenging system (SOD, CAT and GST) exists in the oxygen-metabolizing cells, protecting the cells against free radicals and providing a repair mechanism for oxidized membrane components. $\mathrm{CCl}_{4}$-treated group showed a significant decrease in hepatic antioxidant enzymes, CAT and SOD along with non-enzymatic antioxidant GSH. MDA, the stable metabolite of lipid peroxidation products, was significantly increased upon treatment with $\mathrm{CCl}_{4}$ as observed in group II rats confirmed the hepatic damage by lipid peroxidation and oxidative stress as earlier reported $^{[35]}$. However, pre-treatment with TAETH significantly enhanced the production of CAT, SOD, GSH and inhibited lipid peroxidation, evident from reduced MDA formation in rat liver. It indicates the protective effect of TAETH against $\mathrm{CCl}_{4}$-induced lipid peroxidation in rats due to its antioxidant and radical scavenging capability in a dose-dependent manner. Potent antioxidant phytoconstituents like polyphenols and flavonoids in TAETH played a major role in maintaining the normal level of antioxidant enzymes, integrity of the membrane system, thus reducing lipid peroxidation induced by $\mathrm{CCl}_{4}$ and protecting the liver against damage.

Histopathological examination of liver samples of experimental animals can be correlated to the results of biochemical serum parameters and antioxidant status of the liver. $\mathrm{CCl}_{4}$-treated rats showed extensive cellular injuries characterized by hydropic changes, macro and microvascular steatosis, apoptosis, centrilobular necrosis, ballooning degeneration and fatty deposition.
Necrosis and inflammatory changes induced by $\mathrm{CCl}_{4}$ were remarkably reversed by TAETH. Administration of TAETH $(300 \mathrm{mg} / \mathrm{kg})$ or silymarin $(100 \mathrm{mg} / \mathrm{kg})$ to rats almost normalized the effects of $\mathrm{CCl}_{4}$ enhanced hepatocyte regeneration. From the above results, it is evident that TAETH possessed promising hepatoprotective activity against $\mathrm{CCl}_{4}$-induced liver damage as it significantly lowered the elevated levels of serum parameters, enhanced antioxidant status and inhibited lipid peroxidation as comparable to that offered by silymarin. In addition, the presence of bioactive phytoconstituents like phenols and flavonoids with significant antioxidant, hepatoprotective and antiinflammatory potential in TAETH is primarily acting on the lipid peroxidation process by scavenging the free radicals generated by microsomal reduction of $\mathrm{CCl}_{4}$, boosting the antioxidant capacity of hepatocytes against the reactive oxygen species, inhibition of inflammatory cytokines and hepatocyte regeneration.

The results of this study demonstrated that the ethanol extract of roots of T. akara, was able to attenuate the pathological consequences of $\mathrm{CCl}_{4}$-induced acute liver damage in a dose-dependent manner. This was evident from decreased levels of lipid peroxidation and MDA formation, less fibrotic changes in liver besides the normalization of serum markers of hepatic injury like AST, ALT, ALP, GGT in a way, comparable to that of standard silymarin at higher dose of administration. Moreover, the ethanol fraction showed superior effect on boosting the antioxidant capacity of liver cells as shown by increased level of SOD, CAT and GSH. The hepatoprotective effect of T. akara could be correlated to the high content of antioxidant phytoconstituents like polyphenols and flavonoids, which act as free radical scavengers. Thus, it can be concluded that $T$. akara roots could be considered as a source for developing promising hepatoprotective drug against chemicallyinduced liver damage. However, further studies are required to reveal the bioactive phytoconstituents responsible for the promising hepatoprotective effect of T. akara and to explore their mechanisms of action.

\section{Acknowledgements:}

The authors would like to thank Department of Science and Technology (DST-INSPIRE), India for financial assistance, University of Kerala, Thiruvananthapuram and The Director, KSCSTE-Jawaharlal Nehru Tropical Botanic Garden and Research Institute, Palode for providing necessary facilities. 


\section{Conflicts of interest:}

There are no conflicts of interest.

\section{REFERENCES}

1. Saradamma L, Nair CR, Bhat AV, Jawahar CR, Rajasekharan S. Final Technical Report-All India Co-Ordinate Research Project on Ethnobiology Phase I. Regional Research Institute (Drug Research). Poojapura, Thiruvananthapuram: CCRAS; 1987. p. 141.

2. Ragesh RN, Suja SR, Aneeshkumar AL, Vilash V, Rajasekharan $\mathrm{S}$. A comparative study on quantitative phytochemical analysis and in vitro free radical scavenging activity of various solvent extracts of Tetracera akara (Burm.f.) Merr, an ethnomedicinal plant used by Kani tribe of Kerala. Int J Adv Res 2017;5:190715.

3. Ragesh RN, Suja SR, Aneeshkumar AL, Vilash V, Biju Kumar BS, Rajasekharan S, et al. Acute and Sub-acute oral toxicity studies of ethanolic extract of Tetracera akara (Burm. f.) Merr, an ethnomedicinal plant used by the kani tribe of Kerala. J Tradit Folk Pract 2017;5:71-85.

4. Ragesh RN, Suja SR, Aneeshkumar AL, Vilash V, Rajasekharan S. Antihepatotoxic effect of the ethanolic fraction of roots of Tetracera akara (Burm. f.) Merr., on Acetaminophen induced hepatic damage in Wistar rats. J Pharma Res 2018;12(7):0110.

5. Akindele AJ, Ezenwanebe $\mathrm{KO}$, Anunobi CC, Adeyemi OO. Hepatoprotective and in vivo antioxidant effects of Byrsocarpus coccineus Schum. \& Thonn. (Connaraceae). J Ethnopharmacol 2010;129(1):46-52.

6. Lin $\mathrm{SC}$, Lin $\mathrm{CH}$, Lin $\mathrm{CC}$, Lin $\mathrm{YH}$, Chen $\mathrm{CF}$, Chen IC, et al. Hepatoprotective effects of Arctium lappa Linn. on liver injuries induced by chronic ethanol consumption and potentiated by carbon tetrachloride. J Biomed Sci 2002;9:401-9.

7. Rechnagel RO, Glende EAJ. Carbon tetrachloride hepatotoxicity: an example of lethal cleavage. CRC Crit Rev Toxicol 1973;2:263-297.

8. Reynolds ES. Liver parenchymal cell injury. IV. Pattern of incorporation of carbon and chlorine from carbon tetrachloride into chemical constituents of liver in vivo. J Pharmacol Exp Ther 1967; 155:117-26.

9. Suja SR., Latha PG, Pushpangadan P, Rajasekharan S. Evaluation of hepatoprotective effects of Helminthostachys zeylanica (L.) Hook. against carbon tetrachloride - induced liver damage in Wistar rats. J Ethanopharmacol 2004;92(1): 61-6.

10. Gonzalez-Flecha B, Cutrin JC, Boveris A. Time course and mechanism of oxidative stress and tissue damage in rat liver subjected to in vivo ischemia-reperfusion. J Clin Invest 1993;91(2):456-64.

11. Aebi H. Catalase. In: Bergmeyar HU, editor. Methods of Enzymatic Analysis. New York: Academic Press; 1974. p. 674-84.

12. Kakkar P, Das B, Vishwanathan PN. A modified spectrophotometric assay of superoxide dismutase. Indian $\mathrm{J}$ Biochem Biophys 1984;21(4):130-2.

13. Ellman GL. Tissue sulfhyhryl groups. Arch Biochem Biophys 1959;82(1):70-7.

14. Okhawa H, Ohishi N, Yagi K. Assay for lipid peroxides in animal tissues by thiobarbituric acid reaction. Anal Biochem 1979;95(2):351-9.
15. Nelson SD, Harrison PJ. Roles of cytochrome P450 in chemically induced cytotoxicity. In: Guengrich FP. editor. Mammalian Cytochromes P450. Boca Raton: CRC Press; 1987. p. 19-80.

16. Gruebele A, Zawaski K, Kaplan D, Novak RF. Cytochrome P450 2E1 and cytochrome P450 2B1/2B2-catalyzed carbon tetrachloride metabolism: effects on signal transduction as demonstrated by altered immediate-early (c-Fos and c-Jun) gene expression and nuclear AP-1 and NFkB transcription factor levels. Drug Metab Dispos 1996;24:15-22.

17. Zangar RC, Benson JM, Burnett VL, Springer DL. Cytochrome $\mathrm{P} 4502 \mathrm{E} 1$ is the primary enzyme responsible for low-dose carbon tetrachloride metabolism in human liver microsomes. Chem Biol Interact 2000;15:233-43.

18. Tomasi A, Albano E, Banni S, Botti B, Corongiu F, Dessi MA, et al. Free radical metabolism of carbon tetrachloride in rat liver mitochondria. Biochem J 1987;246:313-7.

19. Castro GD, Gomez MI, Castro JA. DNA bases attack by reactive metabolites produced during carbon tetrachloride biotransformation and promotion of liver microsomal lipid peroxidation. Res Commun Mol Pathol Pharmacol 1997;95(3):253-8.

20. DiRenzo AB, Gandolfi AJ, Sipes IG. Microsomal bioactivation and covalent binding of aliphatic halides to DNA. Toxicol Lett 1982;11:243-52.

21. Mico BA, Pohl LR. Reductive oxygenation of carbon tetrachloride: trichloromethyl peroxy radical as a possible intermediate in the conversion of carbon tetra-chloride to electrophilic chlorine. Arch Biochem Biophys 1983;225:596609.

22. Link B, Dürk H, Thiel D, Frank H. Binding of trichloromethyl radicals to lipids of the endoplasmic reticulum during tetrachloromethane metabolism. Biochem J 1984;233:577-86.

23. Recknagel RO. A new direction in the study of carbon tetrachloride hepatotoxicity. Life Sci 1983;33(5):401-8.

24. Zimmerman HJ, Maddrey WC. Acetaminophen hepatotoxicity with regular intake of alcohol: analysis of instances of therapeutic misadventure. Hepatology 1995;22:767-73.

25. Drotman RB, Lawhorn GT. Serum enzymes as indicators of chemical induced liver damage. Drug Chem Toxicol 1978;1163-71.

26. Jadon A, Bhadauria M, Shukla S. Protective effect of Terminalia belerica Roxb. and gallic acid against carbon tetrachloride induced damage in albino rats. J Ethnopharmacol 2007;109:214-8.

27. Singh B, Saxena AK, Chandan BK, Anand KK. Hepatoprotective activity of verbenalin on experimental liver damage in rodents. Fitoterapia 1998;69:135-40.

28. Rao RR. Mechanism of drug induced hepatotoxicity. Indian J Pharmacol 1973;5(2):313-8.

29. Ochani PC, D’Mello P. Antioxidant and antihyperlipidemic activity of Hibiscus sabdariffa Linn. leaves and calyces extracts in rats. Indian J Exp Biol 2009;47(04):276-82.

30. Dianzani MU, Poli G. Carbon tetrachloride- induced block of hepatic lipoprotein secretion: Studies of the pathogenesis using isolated rat hepatocytes. Front Gastrointest Res 1984;8:1-13.

31. Clawson GA. Mechanisms of carbon tetrachloride hepatotoxicity. Pathol Immunopathol Res 1989;8:104-12.

32. Yang J, Li Y, Wang F, Wu C. Hepatoprotective effects of apple polyphenols on CCl4-induced acute liver damage in mice. $\mathrm{J}$ Agric Food Chem 2010;58:6525-31. 
33. Robbins $\mathrm{M}$, Zhao W. Chronic oxidative stress and radiationinduced late normal tissue injury: a review. Int J Radiat Biol 2004;80:251-9.

34. Yeung JH, Or PM. Effects of polysaccharide peptides from COV-1 strain of Coriolus versicolor on glutathione and glutathione-related enzymes in the mouse. Food Chem Toxicol 2007;45:953-61.

35. Wang C, Chung M, Lichtenstein A, Balk E, Kupelnick B, De Vine D, et al. Effects of omega-3 fatty acids on cardiovascular disease (Summary). Evid Rep Technol Assess 2004;94:1-8. 